AL IBTIDA: JURNAL PENDIDIKAN GURU MI (2021) Vol 8 (2) : 191-204

DOI: http://dx.doi.org/10.24235/al.ibtida.snj.v8i2.8994

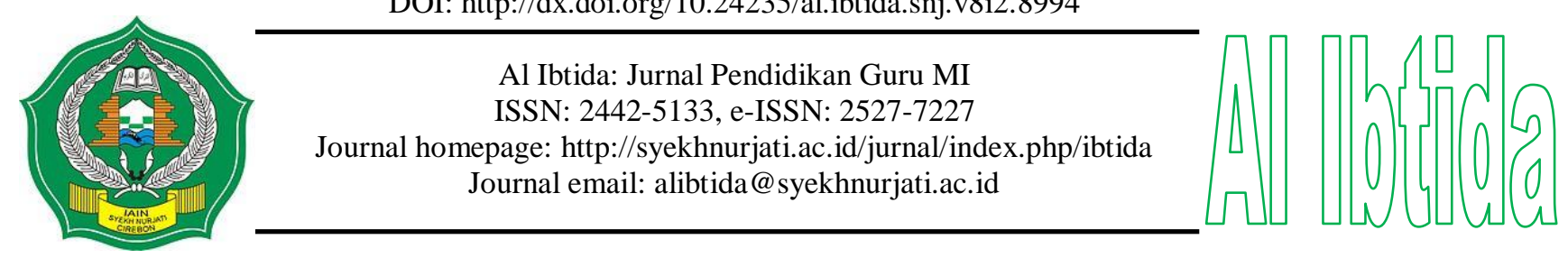

\title{
Elementary School Teachers' Readiness to Engage in Distance Learning and Training during the COVID-19 Pandemic
}

\author{
Yudi Yanuar* \\ *Elementary Education Study Program, School of Postgraduates, \\ Universitas Pendidikan Indonesia, Indonesia. \\ Email: yudiyanuar@upi.edu \\ Wawan Setiawan** \\ **Elementary Education Study Program, School of Postgraduates, \\ Universitas Pendidikan Indonesia, Indonesia. \\ Email: wawans@upi.edu \\ Wahyu Sopandi*** \\ ***Elementary Education Study Program, School of Postgraduates, \\ Universitas Pendidikan Indonesia, Indonesia. \\ Email: wsopandi@upi.edu
}

\author{
Atep Sujana**** \\ ****Elementary Education Study Program, School of Postgraduates, \\ Universitas Pendidikan Indonesia, Indonesia. \\ Email: wsopandi@upi.edu \\ Mohamad Adning***** \\ ****Doctoral Researcher, Brunel University London, United Kingdom \\ Email: mohamad.adning@brunel.ac.uk
}

Received: September 16 $6^{\text {th }}$ 2021. Accepted: October 15 ${ }^{\text {th }}, 2021$. Published: October $30^{\text {th }}, 2021$.

\begin{abstract}
The readiness of elementary school teachers during the COVID-19 pandemic to engage in distance learning is the basis for developing a training mode for teachers. This study aims to ensure the readiness of elementary school teachers to participate in distance learning and training during the COVID-19 pandemic. In this study, descriptive quantitative is used with online survey techniques. The research subjects were 85 elementary school teachers in Indonesia who voluntarily filled out a questionnaire. The data were collected through a questionnaire instrument with a Likert scale and open-ended questions. The data were analyzed by calculating the average of each item and making a percentage. Research findings indicate that $37.22 \%$ of the respondents were ready to engage in distance learning and training with a blended mode. They used various applications such as WhatsApp, Google Classroom, Google Form, and YouTube.
\end{abstract}

Keywords: teachers' readiness, elementary school, distance learning, training. 


\begin{abstract}
Abstrak
Kesiapan guru SD di masa pandemi COVID-19 untuk mengikuti pembelajaran jarak jauh menjadi dasar pengembangan model pelatihan bagi guru. Penelitian ini bertujuan untuk memastikan kesiapan guru sekolah dasar untuk mengikuti pembelajaran dan pelatihan jarak jauh selama pandemi COVID-19. Dalam penelitian ini digunakan deskriptif kuantitatif dengan teknik survei online. Subyek penelitian adalah 85 guru sekolah dasar di Indonesia yang secara sukarela mengisi angket. Pengumpulan data dilakukan melalui instrumen angket dengan skala likert dan pertanyaan terbuka. Data dianalisis dengan menghitung rata-rata setiap item dan membuat persentase. Temuan penelitian menunjukkan bahwa $37,22 \%$ responden siap untuk terlibat dalam pembelajaran dan pelatihan jarak jauh dengan mode campuran. Mereka menggunakan berbagai aplikasi seperti WhatsApp, Google Classroom, Google Form, dan YouTube.
\end{abstract}

Kata kunci: kesiapan guru, sekolah dasar, pembelajaran jarak jauh, pelatihan.

\title{
INTRODUCTION
}

Readiness is a term used to describe a person's condition in dealing with everything. Everyone has different needs that can influence his readiness. In literature, the term readiness can be interpreted as an overall condition in terms of strength, physical, and mental that makes a person ready in responding to situations encountered in the development process (Dalyono, 2005; Hamalik, 2008; Korth et al., 2009; Slameto, 2010). One's readiness is essential in learning since it will affect a person's learning process and the results obtained.

The three main components of the learning process are students, teacher competence, and learning facilities (Murtiyasa, 2012). Among these components, teachers play a pivotal role in teaching and learning process both inside and outside the classroom, especially in the digital era of the $21^{\text {st }}$ century (Srinivasacharlu, 2019). The competencies of teachers are expected to improve along with the times. In addition, new learning models, strategies, and designs have emerged so that teachers need to open themselves to have an understanding on it (Muti'ah et al., 2021; Yanuar \& Widodo, 2021). Therefore, according to Srinivasacharlu (2019), teachers must improve their competence to update their knowledge and skills through Continuing Professional Development (henceforth CPD) activities.

Improving teacher competence through CPD activities is regulated by the government of Indonesia with the issuance of a ministerial regulation concerning Teacher Functional Positions and Credit Scores. In this regulation, CPD is defined as the process of developing teacher competencies on a need-to-need basis, gradually and continuously, to enhance their expertise. The goal is for teachers to keep, enhance, and open up their knowledge and expertise necessary to conduct the teaching-learning activities professionally in the classroom to demonstrate high-quality learning. CPD activities are divided into three categories, namely 
self-development, scientific reports, and innovative works (Kemendikbud, 2016). Not only in Indonesia, CPD is also carried out by teachers in other countries with plans and ideas for their professional future (Van der Klink et al., 2017). CPD is related to the teaching profession as a lifelong learning process, and it is good that it is from the teacher's initiative (Tyagi \& Misra, 2021). CPD empowers teachers in schools through a bottom-up approach rather than a topdown approach. It is hoped that teachers are motivated to participate in CPD activities to enhance their professionalism (Wyatt \& Ager, 2017).

Functional education and training are examples of teachers' activities for selfdevelopment. According to the Regulation of the Head of the State Administration Agency of the Republic of Indonesia, functional education and training is education and training carried out to achieve competency requirements according to each functional level. The number of Indonesian teachers, especially elementary school teachers, is 1,464,747 people. (Kemendikbud, 2020). Large budgets are needed to organize training for all these teachers and it takes a long time to conduct face-to-face training. Thus, the government spending is needed to organize these activities, including accommodation, transportation, and training participants' pocket money. In addition to resource and time, budget also becomes an obstacle for teachers if they should pay it independently (Van der Klink et al., 2017). The ICT growth in the 21 st century allows teachers to attend online training instead of face-to-face meeting. Therefore, it is necessary to use ICT to increase the teachers' competence through functional training (Ugur et al., 2021). Another effect is that teachers have to leave their class for a few days to participate in training activities (Susilawati, 2016). Not all teachers can participate in the training due to the limited quota of training participants from each training institution.

Today, the COVID-19 accelerates the adoption of Education 4.0 to address future possibilities (Hussin, 2018). This is in line with the government policies that prohibit traditional learning activities and encourage the implementation of online learning. The new era of digital transformation (Cropley \& Patston, 2019; Setiawan, 2017) leads to the today's globalized, competitive, diverse, and complex era so that in carrying out online learning, teachers must be able to use ICT and have digital literacy skills improve the learning quality (Arifuddin et al., 2021; Lestari et al., 2021; Sujana \& Rachmatin, 2019).

Distance learning has become a necessity for everyone in learning (Dhawan, 2020). Previous research stated that teachers were highly motivated in conducting online training, especially in accessing the features presented in the online learning system (Susilawati, 2018). Ismail et al. (2018) stated that distance learning could improve digital literacy and learning styles, and the learning process becomes more interesting by utilizing interactive learning 
media. In a study that combines online and face-to-face learning, it was found that there was a significant association between perceived learning and satisfaction but no significant difference between an instructor and student perspectives (Karimi \& Ahmad, 2020). It was also found in the research of Krasnova \& Shurygin (2019) that blended learning is more effective to be implemented using the learning management system. Blended learning according to the experts is a mix of face-to-face and online learning that allows students to experience learning similar to the face-to-face meeting (Hamdi \& Abu Qudais, 2018). Blended learning consists of three main pillars: direct interaction with traditional face-to-face meeting and the use technology, and learning independently (Krasnova \& Shurygin, 2019). Those different learning strategies are needed, especially in content delivery, learner activities, materials, and regulatory competencies that use a lot of ICT equipment and online digital applications (Byrka, 2017).

Based on the previous findings, it is interesting to know the readiness of elementary school teachers in Indonesia in implementing distance learning and training. Especially in the times of the COVID-19 pandemic, it is possible to conduct distance learning as a practice in the new normal life. For this reason, this study examines the elementary school teachers' readiness to engage in distance learning and training during the COVID-19 pandemic. It is hoped that this research can be used as a preliminary study before developing a distance training mode for elementary school teachers using innovative learning models such as RADEC learning model (Handayani et al., 2019; Sopandi, 2017).

\section{METHODS}

This study uses a descriptive quantitative method with survey techniques (Gall et al., 2010) to describe the readiness of elementary school teachers to participate in distance learning and training during the COVID-19 pandemic, both as a result of phenomena and events (Suter, 2012) from the group in one time or change from time to time. However, this study did not explore causal relationships (Gall et al., 2010).

The population of this study was 150 teachers in Indonesia. They attended online workshops of educational organizations and voluntarily filled out questionnaires related to distance learning and training during the COVID-19 pandemic. Thus, the respondents were 85 elementary school teachers from 150 teachers from 10 provinces and 31 districts/cities. The ages of respondents were < 30 years (17 people), 30 - 39 years (34 people), 40 - 49 years (14 people), and $>50$ years ( 20 people). The teaching experiences of respondents were $<5$ years (14 people), 5-9 years (15 people), 10-19 years (43 people), and >20 years (13 people). 
Data were collected using online survey techniques using a questionnaire consisting of 4 indicators and 14 statements with a Likert scale $(1=$ Strongly Agree, $2=$ Agree, $3=$ Neutral, 4 = Disagree, 5 = Strongly Disagree), and five open-ended questions. The four indicators are about understanding ( 3 statements), objectives (4 statements), characteristics (5 statements), and evaluation (2 statements) about distance learning. The data from the questionnaire were processed by calculating each score from each item. The average score was calculated as a percentage to get an idea of the teacher's readiness for distance learning. Meanwhile, open questions were used to know the applications commonly used by teachers and the desired mode of training. The respondents' answers were processed into percentages to see the tendency of the respondents.

\section{RESULTS AND DISCUSSION}

Based on the online questionnaire regarding the readiness of elementary school teachers, the data were analyzed for each aspect. The results of the analysis can be presented as follows.

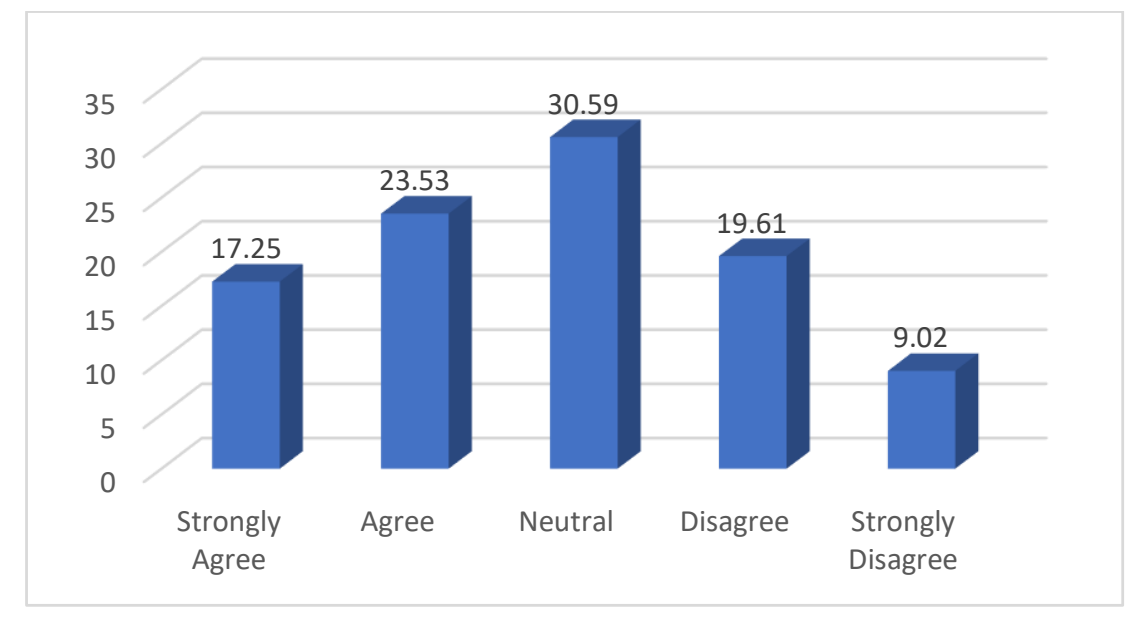

Graph 1. Results Indicators on Understanding Distance Learning

Graph 1 shows that most of the respondents strongly agreed and agreed with the statement of understanding. It is stated that $40.78 \%$ of the respondents have understood distance learning. Students' knowledge of the material presented is very dependent on the clarity of the presentation from the teacher and the learning targets. Therefore, teachers have to understand distance learning. It is not only about the content that will be delivered online, but also how to deliver it, what media is suitable for the content, work system, student characteristics, and others. Thus, distance learning is not a problem but a solution during the pandemic. Similar to previous research, teachers understand that distance learning can be a solution for implementing learning (Susilawati, 2016) by paying attention to the distance 
learning work system (Bylaitė-Šalavèjien, 2021). It is expected that teachers can develop effective learning with the ideas that they have (Yengin et al., 2010). Teachers' understanding of distance learning can also be seen in their teaching and learning activities (Lepp et al., 2021; UNESCO, 2020).

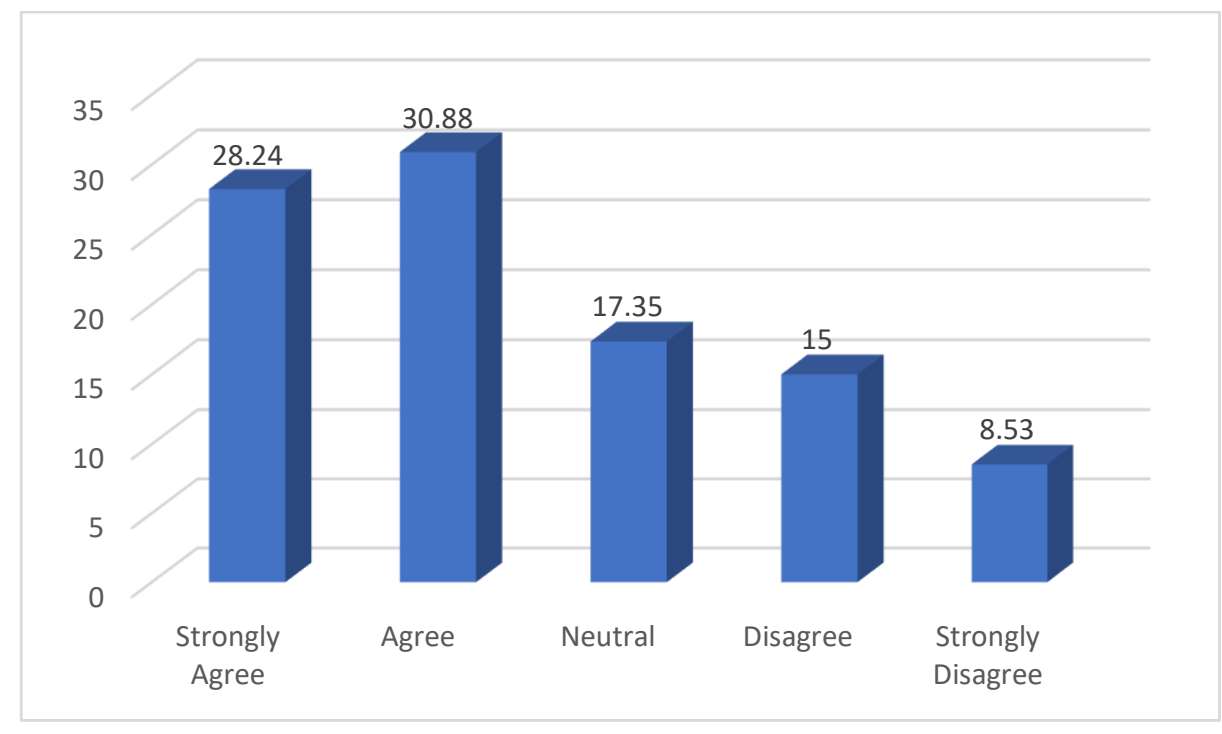

Graph 2. Results Indicators on Distance Learning Goals

Most of the respondents strongly agreed and agreed with the statement regarding the objectives, as shown in Graph 2. It is interpreted that $59.12 \%$ of the respondents understand the goals of distance learning. Distance learning can improve the digital literacy of teachers and students. Students themselves can be more creative and think critically; they can also communicate and collaborate. Meanwhile, teachers become innovative in creating content. Previous research has also stated that collaboration is needed in the implementation of distance learning, so that it needs to be designed well in advance (Papanikolaou et al., 2017). Distance learning can also make students critical, creative, communicate and collaborate (Dhawan, 2020; Hamdi \& Abu Qudais, 2018; Qu, 2018). In adopting distance learning, teachers must also pay attention to the learning objectives to be achieved by adjusting to the learning strategies used (UNESCO, 2020). 
Yudi Yanuar, Wawan Setiawan, Wahyu Sopandi, Atep Sujana, Mohamad Adning, Elementary School Teachers' Readiness to Engage in Distance Learning...

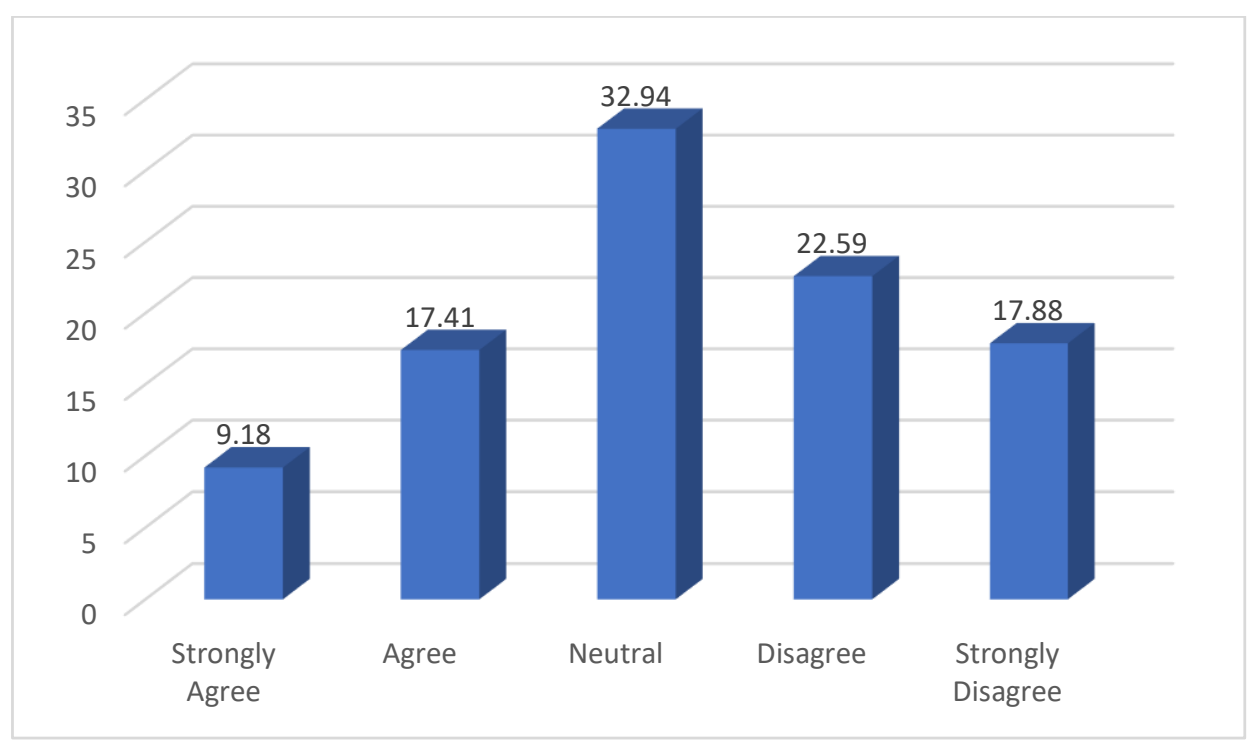

Graph 3. Results Indicators on the Characteristics of Distance Learning

Regarding the characteristics, most of the respondents disagreed and strongly disagreed with the statement. This indicates that $40.47 \%$ of the respondents do not know precisely about distance learning elements. At the same time, distance learning can make students active and more independent in learning by involving parents at home but not burdening them. Students must be active and independent so that they can understand what they are learning. Otherwise, students will be left behind compared to other students. This result is in line with previous research that found that students can learn independently (Byrka, 2017; Qu, 2018; Roff, 2021) and is also more active (Hidayat et al., 2019; Qasem \& Viswanathappa, 2016) in distance learning.

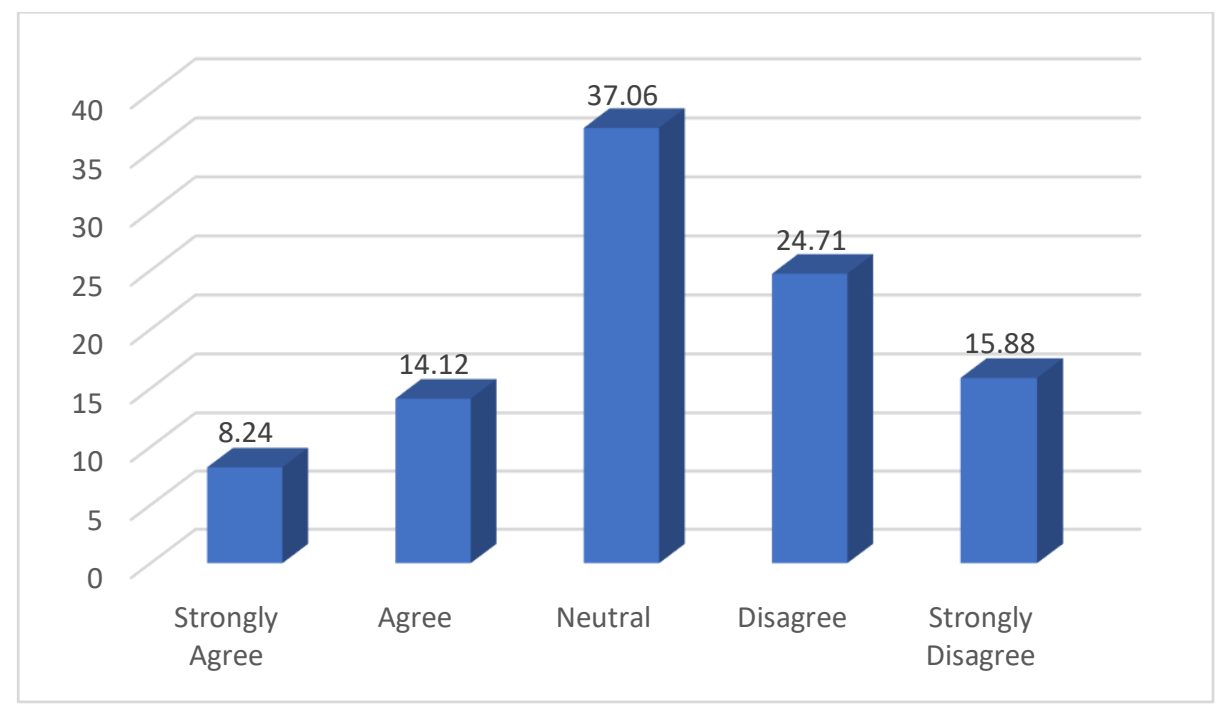

Graph 4. Results Indicators on the Evaluation of Distance Learning 
Most of the respondents stated that they did not agree and strongly disagreed with the evaluation. Respondents stated that evaluation in distance learning is not the same as face-toface learning and it becomes more troublesome. In essence, evaluation in distance learning is the same as face-to-face learning but it uses different assessment media, such as using online surveillance cameras during evaluation (Woldeab \& Brothen, 2021). Another study states that the differences between participants and their needs can be adjusted by online assessment using existing online applications (Bin Mubayrik, 2020) and more effective if it is conducted online (Ugur et al., 2021). For this reason, teachers must understand how to use online assessment media and get rid of the stigma that online evaluation is a hassle (UNESCO, 2020).

Overall, the respondents stated that they strongly agreed and agreed with the statements provided. It means that $37.22 \%$ of the elementary school teachers are ready to conduct distance learning. They can understand the meaning of distance learning, understand its goals, and know its characteristics. However, the teacher argues that assessment in distance learning is different from face-to-face learning. Basantia's research (2018) states that the special preparations as well as assistance in terms of the facilities and infrastructure are needed for implementing distance learning.

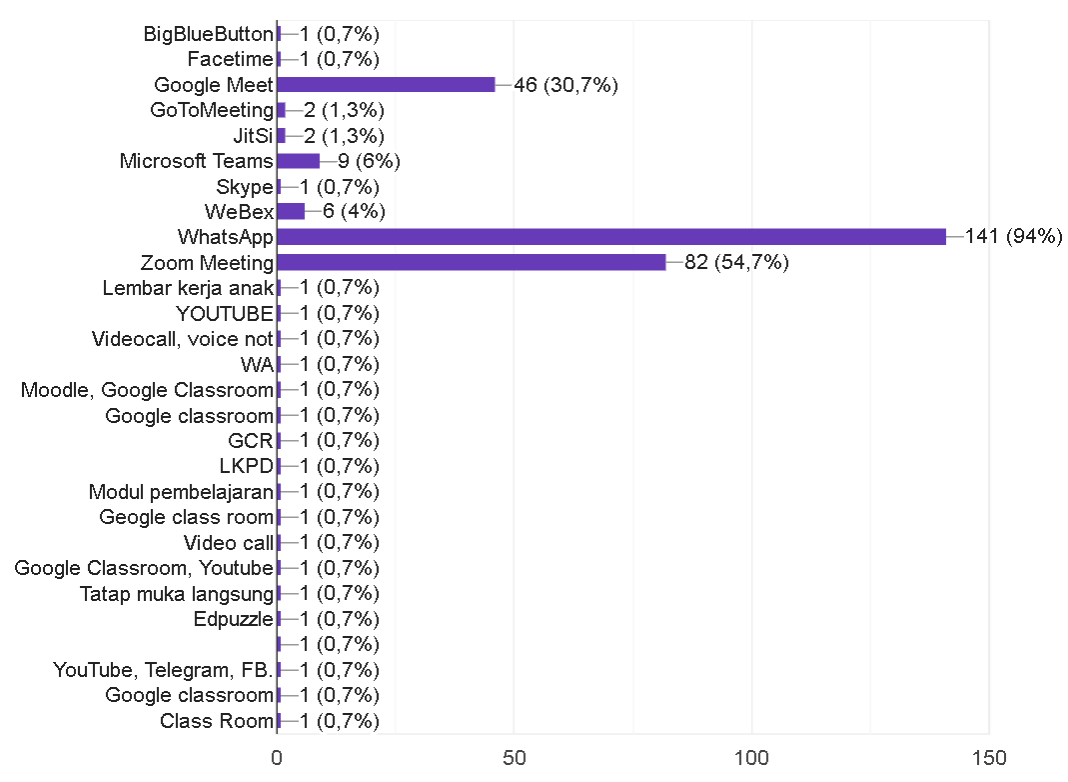

Figure 1. Applications commonly used by teachers for online discussions

According to Figure 1, the researcher asks questions about applications commonly used for online discussions. Respondents may choose more than one frequently used application. Most teachers are accustomed to using WhatsApp, Zoom Meeting, and then Google Meet as a communication medium in online discussions. Especially for WhatsApp, everyone has this 
application on their smartphones, which are used widely for purposes outside of education. But this can also be used today for educational purposes, especially for learning. This app can be used for discussions and sharing links or files in documents, photos, and videos.

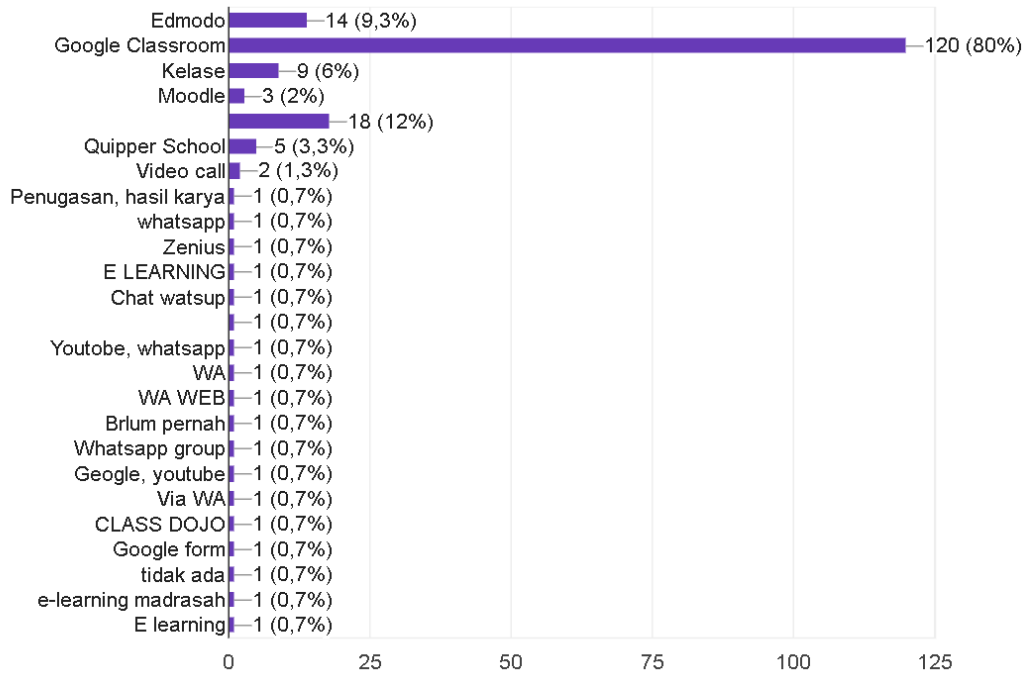

Figure 2. Commonly used Learning Management System (LMS) applications

In addition, most respondents are accustomed to using Google Classroom as a Learning Management System (LMS) in delivering material and assignments, as shown in Figure 2. However, a few of them use other LMS, such as Edmodo, Kelase, Moodle, and others. Their preference of Google Classroom can be due to the ease of use of the app and its simple but powerful appearance. It can also be easily connected to all Android-based smartphones.

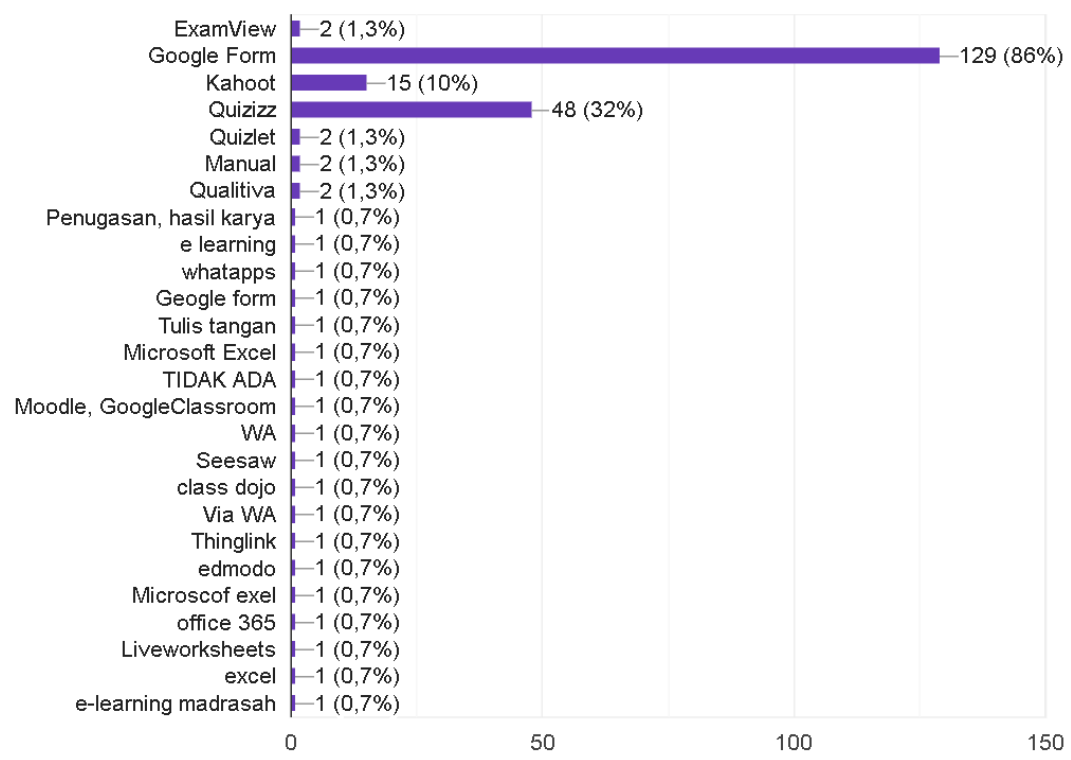

Figure 3. Applications commonly used for assessment 
As for the assessment, almost all respondents used Google Form, although some used Quizizz, Kahoot, and other applications, as shown in Figure 3. Google Form is also easy to use for making assessments, which can be made in multiple-choice or filling. The results can automatically be recapitulated by the application for multiple-choice purposes, making it easier for teachers to use them.

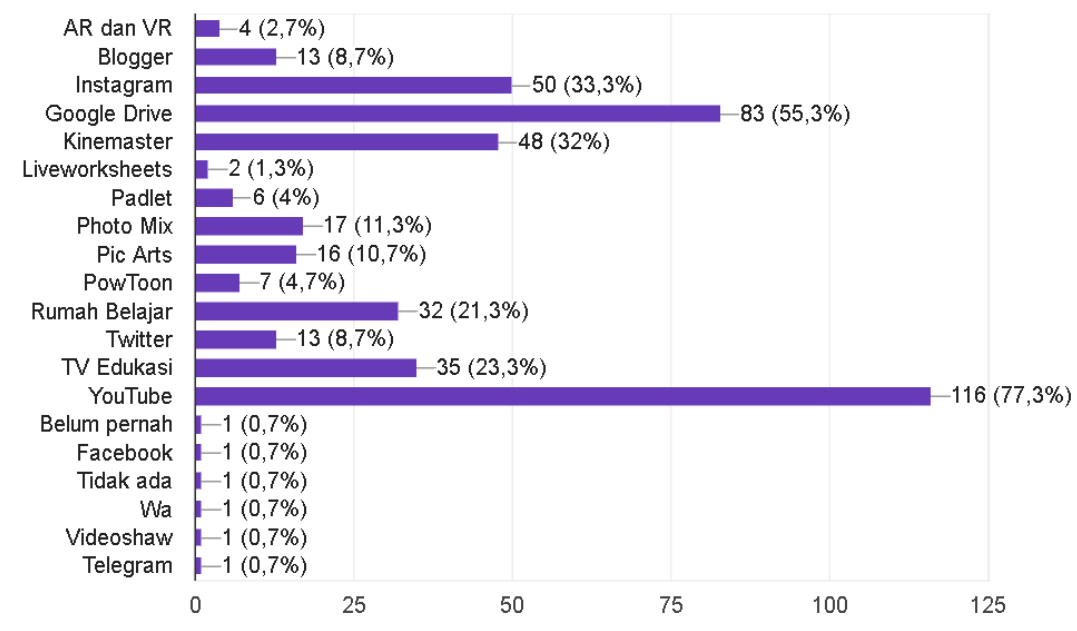

Figure 4. Applications commonly used as learning media

Most respondents are accustomed to using videos by uploading them on YouTube, as shown in Figure 4. The teachers utilize Google applications to deliver learning materials and assignments via Google Classroom, communication via Google Meetings, and assessment via Google Forms.

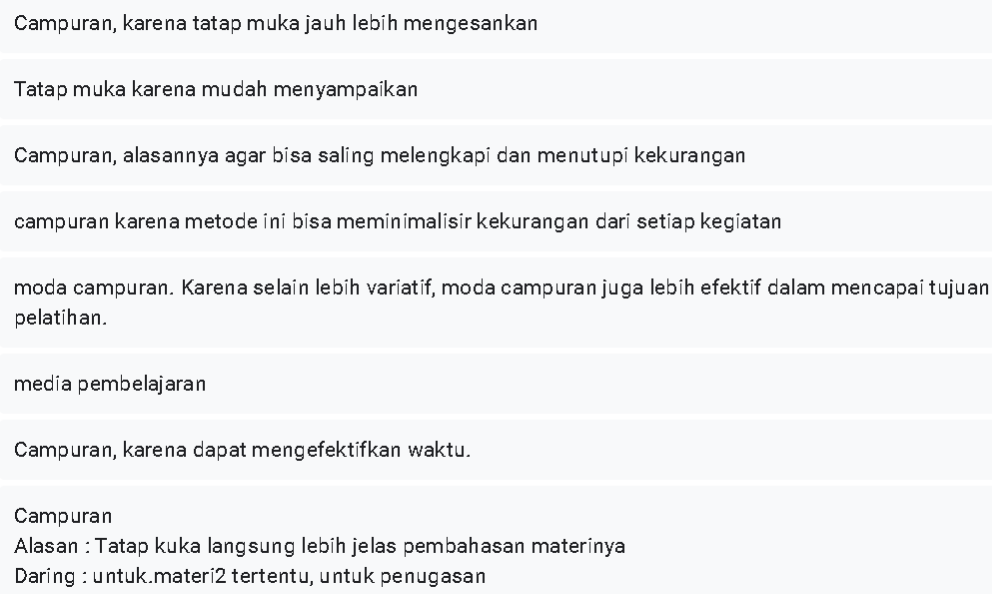

Figure 5. The training mode chosen by the COVID-19 pandemic

Regarding the training mode during the pandemic, most respondents chose mixed or blended training, as shown in Figure 5. Respondents can use technology and also learn to be more independent while being monitored. Things that cannot be understood during an 
independent study can be discussed face-to-face with other participant facilitators. These results are in line with previous research on blended learning or training. Sari (2014) stated an increase in good interaction between participants, facilitators, and learning resources can be achieved through implementing blended learning. Hamdi and Qudais (2018) also state that blended learning is more effective than the traditional and full online learning. In addition, blended learning is also potential to be implemented because online training is not better than traditional training (Wuryaningsih et al., 2019)

\section{CONCLUSION}

The research findings provide an overview that teachers are generally ready with distance learning and training during the COVID-19 pandemic. In addition, teachers prefer blended learning for training in CPD activities because they have been accustomed to implementing distance learning. Some implications can be proposed for further research, such as investigating the teacher's training mode for elementary school. Studies are needed to discuss how the innovative learning model can be used in elementary school teacher training with mixed or blended modes to increase the teacher competence. As for professional practice, these findings could be a reference to teachers regarding the implementation of blended training.

\section{REFERENCES}

Arifuddin, A., Turmudi, \& Rokhmah, U. N. (2021). Alternative Assessments in Online Learning at Elementary Education during Covid-19 Pandemic: The Strenghths and Weaknesses. International Journal of Elementary Education, 5(2), 240-247.

Basantia, T. K. (2018). Implementing practical based courses under open and distance learning system: A study of the perception of learners and counsellors. Turkish Online Journal of Distance Education, 19(2), 201-214. https://doi.org/10.17718/tojde.415838

Bin Mubayrik, H. F. (2020). New Trends in Formative-Summative Evaluations for Adult Education. SAGE Open, 10(3). https://doi.org/10.1177/2158244020941006

Bylaitè-Šalavejjien, D. (2021). Distance learning during the COVID-19 pandemic: School barometer Lithuania. Socialinis Ugdymas, 54(2), 51-61. https://doi.org/10.15823/su.2020.54.4

Byrka, M. F. (2017). Blended Learning Strategy in Teacher Training Programs. Information $\begin{array}{llll}\text { Technologies and Learning } & \text { Tools, }\end{array}$ https://doi.org/10.33407/itlt.v62i6.1802

Cropley, D. H., \& Patston, T. J. (2019). Creativity Under Duress in Education? Resistive Theories, Practices, and Actions. In Creativity Under Duress in Education? Resistive Theories, Practices, and Actions (Issue January, pp. 267-288). Springer. https://doi.org/10.1007/978-3-319-90272-2 
Dalyono. (2005). Psikologi Pendidikan. PT Rineka Cipta.

Dhawan, S. (2020). Online Learning: A Panacea in the Time of COVID-19 Crisis. Journal of Educational Technology Systems, 49(1), 5-22. https://doi.org/10.1177/0047239520934018

Gall, M. D., Gall, J. P., \& Borg, W. R. (2010). Applying Educational Research (6th ed.). Pearson Education, Inc.

Hamalik, O. (2008). Perencanaan Pengajaran Berdasarkan Pendekatan Sistem. Bumi Aksara.

Hamdi, T., \& Abu Qudais, M. (2018). Optimising the blended learning environment: the Arab Open University experience. Open Learning, 33(1), 46-62. https://doi.org/10.1080/02680513.2017.1414587

Handayani, H., Sopandi, W., Syaodih, E., Setiawan, D., \& Suhendra, I. (2019). Dampak Perlakuan Model Pembelajaran RADEC Bagi Calon Guru Terhadap Kemampuan Merencanakan Pembelajaran di Sekolah Dasar. Pendas : Jurnal Ilmiah Pendidikan Dasar, IV , 79-93. https://doi.org/10.23969/jp.v4i1.1857

Hidayat, M. L., Prasetiyo, W. H., \& Wantoro, J. (2019). Pre-service student teachers' perception of using google classroom in a blended course. Humanities and Social Sciences Reviews, 7(2), 363-368. https://doi.org/10.18510/hssr.2019.7242

Hussin, A. A. (2018). Education 4.0 Made Simple: Ideas For Teaching. International Journal $\begin{array}{llll}\text { of Education } & \text { and Literacy }\end{array}$ https://journals.aiac.org.au/index.php/IJELS/article/view/4616

Ismail, M. E., Utami, P., Ismail, I. M., Hamzah, N., \& Harun, H. (2018). Development of massive open online course (MOOC) based on addie model for catering courses. Jurnal Pendidikan Vokasi, 8(2), 184. https://doi.org/10.21831/jpv.v8i2.19828

Karimi, L., \& Ahmad, T. B. T. (2020). Perceived Learning and Satisfaction in a Blended Teacher Education Program: An Experience of Malaysian Teacher Trainees. Contemporary Educational Technology, 4(3), 197-211. https://doi.org/10.30935/cedtech/6103

Karwowski. et al. (2020). The creative student in the eyes of a teacher: A cross-cultural study. Thinking Skills and Creativity, 35(February), 100636. https://doi.org/10.1016/j.tsc.2020.100636

Kemendikbud. (2016). Buku 4: Pedoman Kegiatan Pengembangan Keprofesian Berkelanjutan dan Angka Kreditnya. Ditjen GTK.

Kemendikbud. (2020). Data Pokok Pendidikan. https://dapo.dikdasmen.kemdikbud.go.id/guru

Korth, B. B., Erickson, L., \& Hall, K. M. (2009). Defining Teacher Educator Through the Eyes of Classroom Teachers. The Professional Educator, 33(1), 1-12. http://myaccess.library.utoronto.ca/login?url=http://search.proquest.com/docview/19 4687907?accountid=14771\%5Cnhttp://bf4dv7 zn3u.search.serialssolutions.com/?ctx_ ver=Z39.88-2004\&ctx_enc=info:ofi/enc:UTF8\&rfr_id=info:sid/ProQ:educationalumni\&rft_val_fmt=in

Krasnova, L., \& Shurygin, V. (2019). Blended learning of physics in the context of the professional development of teachers. International Journal of Emerging Technologies in Learning, 14(23), 17-32. https://doi.org/10.3991/ijet.v14i23.11084 
Lepp, L., Aaviku, T., Leijen, Ä., Pedaste, M., \& Saks, K. (2021). Teaching during COVID19: The decisions made in teaching. Education Sciences, 11(2), 1-21. https://doi.org/10.3390/educsci11020047

Lestari, I., Setiawan, W., \& Muqodas, I. (2021). Online Learning Behavior During COVID-19 Pandemic toward Students' Digital Literacy Skills. International Conference on Elementary $\quad$ Education,
http://proceedings2.upi.edu/index.php/icee/article/view/1506

Murtiyasa, B. (2012). Pemanfaatan Teknologi Informasi dan Komunikasi Untuk Meningkatkan Kualitas Pembelajaran Matematika. FKIP Univ. Muhammadiyah Surakarta. https://doi.org/10.29103/TECHSI.V9I2.214

Muti'ah, U. N., Retnawati, H., Senen, A., \& Kassymova, G. K. (2021). Teaching Collaborations in Elementary Schools: Teachers' Understanding, Strategies, and Obstacles. Al Ibtida: Jurnal Pendidikan Guru MI, 8(1), 1. https://doi.org/10.24235/al.ibtida.snj.v8i1.7519

Papanikolaou, K., Makri, K., \& Roussos, P. (2017). Learning design as a vehicle for developing TPACK in blended teacher training on technology enhanced learning. International Journal of Educational Technology in Higher Education, 14(1). https://doi.org/10.1186/s41239-017-0072-z

Qasem, A. A. A., \& Viswanathappa, G. (2016). Teacher perceptions towards ICT integration: Professional development through blended learning. Journal of Information Technology Education: Research, 15, 561-575. https://doi.org/10.28945/3562

Qu, C. (2018). Application of network technology in distance education of physical education curriculum-take the football course as an example. Kuram ve Uygulamada Egitim Bilimleri, 18(5), 2354-2362. https://doi.org/10.12738/estp.2018.5.134

Roff, K. (2021). Superintendents 'Experiences with Distance Learning Practices in K - 12 Public-School Districts in New York During the COVID-19 Pandemic Expériences des Surintendants en Matière de Pratiques de Formation à Distance dans les Districts Scolaires Publics de. 36(1), 1-37.

Sari, M. (2014). The Use of Facebook in Blended Course in Teacher Training College. Al-Ta Lim Journal, 21(2), 145-153. https://doi.org/10.15548/jt.v21i2.92

Setiawan, W. (2017). Era Digital dan Tantangannya. Seminar Nasional Pendidikan 2017.

Slameto. (2010). Belajar dan faktor-faktor yang Mempengaruhinya. PT. Rineka Cipta Subadi.

Sopandi, W. (2017). The quality improvement of learning processes and achievements through the read-answer-discuss-explain-and create learning model implementation. Proceeding 8th Pedagogy International Seminar 2017: Enhancement of Pedagogy in Cultural Diversity Toward Excellence in Education, 8(229), 132-139.

Srinivasacharlu, A. (2019). Continuing Professional Development (CPD) of Teacher Educators in 21st Century. Shanlax International Journal of Education, 7(4), 29-33. https://doi.org/10.34293/education.v7i4.624

Sujana, A., \& Rachmatin, D. (2019). Literasi digital abad 21 bagi mahasiswa PGSD: apa, mengapa, dan bagaimana. Conference Series Journal, 1(1).

Susilawati, E. (2016). Analisis SWOT penyelenggaraan diklat online teknologi informasi dan komunikasi (TIK) bagi guru (SWOT analysis of the implementation of online ICT training for teachers). Jurnal Pendidikan Dan Kebudayaan, 1(3), 349-364. 
https://doi.org/http://dx.doi.org/10.24832\%2Fjpnk.v1i3.395

Susilawati, E. (2018). Dampak Program Diklat Online TIK Guru PUSTEKKOM Terhadap Aksesibiltas Konten Pembelajaran pada Fitur Rumah Belajar. Jurnal Pendidikan, 19(2), 84-103.

Suter, W. N. (2012). Introduction to Educational Research. A Critical Thinking Approach (Second Edi). SAGE Publications. https://doi.org/10.1080/1047621870010222

Tyagi, C., \& Misra, P. K. (2021). Continuing Professional Development of Teacher Educators: Challenges and Initiatives. Shanlax International Journal of Education, 9(2), 117-126. https://doi.org/10.34293/education.v9i2.3634

Ugur, B., Arkun Kocadere, S., Nuhoglu Kibar, P., \& Bayrak, F. (2021). AN OPEN ONLINE COURSE TO ENHANCE. Turkish Online Journal of Distance Education-TOJDE, 22(4), 24-42.

UNESCO. (2020). Ensuring effective distance learning during COVID-19 disruption. Guidance for teachers. 1-79. http://www.unesco.org/open-access/terms-use-ccbysaen

Van der Klink, M., Kools, Q., Avissar, G., White, S., \& Sakata, T. (2017). Professional development of teacher educators: what do they do? Findings from an explorative international study. Professional Development in Education, 43(2), 163-178. https://doi.org/10.1080/19415257.2015.1114506

Woldeab, D., \& Brothen, T. (2021). Video Surveillance of Online Exam Proctoring: Exam Anxiety and Student Performance Surveillance vidéo d' examens en ligne : anxiété liée à 1 ' examen et performance des étudiants. International Journal of E-Learning and Distance Education, 36(1), 1-26.

Wuryaningsih, Susilastuti, D. H., Darwin, M., \& Pierewan, A. C. (2019). Effects of webbased learning and F2F learning on teachers achievement in teacher training program in Indonesia. International Journal of Emerging Technologies in Learning, 14(21), 123-147. https://doi.org/10.3991/ijet.v14i21.10736

Wyatt, M., \& Ager, E. O. (2017). Teachers' cognitions regarding continuing professional development. ELT Journal, 71(2), 171-185. https://doi.org/10.1093/elt/ccw059

Yanuar, Y., \& Widodo, A. (2021). Pengaruh Desain Pembelajaran Berbasis Nature of Science terhadap. Jurnal Inspirasi Pendidikan, 11(1), 10-18. https://doi.org/10.21067/jip.v11i1.5043

Yengin, I., Karahoca, D., Karahoca, A., \& Yücel, A. (2010). Roles of teachers in e-learning: How to engage students \& how to get free e-learning and the future. Procedia Social and Behavioral Sciences, 2(2), 5775-5787. https://doi.org/10.1016/j.sbspro.2010.03.942 